Chapter published in the The Palgrave Encyclopedia of Imperialism and Anti-Imperialism, 2019 The publication is available at: https://doi.org/10.1007/978-3-319-91206-6_125-2

To cite this article: Cruz-Martinez G. (2019) Puerto Rico, Colonialism, and Neocolonialism. In: Ness I., Cope Z. (eds) The Palgrave Encyclopedia of Imperialism and Anti-Imperialism. Palgrave Macmillan, Cham, DOI: 10.1007/978-3-319-91206-6_125-2

\title{
Puerto Rico, Colonialism, and Neocolonialism
}

\author{
Gibrán Cruz-Martínez \\ Institute of Public Goods and Policies, CSIC \\ gibran.cruz@csic.es
}

\begin{abstract}
:
This essay aims to briefly collect the historical context of colonialism in Puerto Rico since the Spanish era but primarily focuses on revealing the reasons to consider Puerto Rico as a colony and non-self-governing territory of the US - rather than a neocolony of the US. Later, the article addresses the three non-colonial options recognized by the 1514 United Nations (UN) Resolution and the results of the five referendums on the political status of the Caribbean archipelago held over the last five decades. The essay concludes that Puerto Rico is undoubtedly a colony and asks for the United Nations and the sovereign countries of the world to denounce this illegal colonial relationship that subordinates residents of Puerto Rico to the will of the US Congress where they have no voting representatives.
\end{abstract}

Keywords: Caribbean; Imperialism; Latin America; Small island state; United States 


\section{Description}

Puerto Rico was a Spanish colony from 1508 to 1898 and has been officially an unincorporated territory of the United States (US) since 1898. Simply put, Puerto Rico is a colony of the US subordinated to the plenary powers of the US Congress under the Territorial Clause of the US Constitution. The three branches of US government, Puerto Rican politicians, United Nations, and academics around the world have confirmed the colonial status of the Caribbean archipelago. Puerto Rico cannot be considered a neocolony because the US has direct control of the archipelago.

\section{Introduction}

A US Republican congressman from Arkansas recently stated, "I think it is time that America should stop colonising. (...) The great America of the United States has a colony, and I think it is time that we change that" (Young 2017). Colonialism is imbricated in Puerto Rican history. According to Dietz (2002), colonialism has imposed limits of action on Puerto Ricans and has established the "rules of the game." This is a historical fact and has been a reality during the Spanish and the US colonial rule of the Caribbean archipelago.

Puerto Rico's relationship with the US is openly described in the Territorial Clause of the Constitution of the United States of America (Article IV, section 3, Clause 2): “The [US] Congress shall have Power to dispose of and make all needful Rules and Regulations respecting the Territory or other Property belonging to the United States." Throughout the US colonial period, the three branches of the US government have repeatedly confirmed the colonial status of Puerto Rico. In 2016 the three branches of the US government confirmed that Puerto Rico is not sovereign and is subjected to the US Congress, revealing the lack of political and juridical sovereignty of Puerto Rico (Denis 2017; Newkirk 2016; Wolf 2016). The colonial domination of the US Congress over Puerto Rico was recently reconfirmed with the imposition of an unelected financial control board, which has not only imposed an austerity program since late 2016 but also took control of legislation enacted by the Puerto Rican elected government, arguing that all new laws must be consistent with the board's Fiscal Plan.

This essay aims to briefly collect the historical context of colonialism in Puerto Rico since the Spanish era but primarily focuses on revealing the reasons to consider Puerto Rico as a colony and non-self-governing territory of the US - rather than a neocolony of the US. Later, the article addresses the three non-colonial options recognized by the 1514 United Nations (UN) Resolution and the results of the five referendums on the political status of the Caribbean archipelago held over the last five decades. The essay concludes that Puerto Rico is undoubtedly a colony and asks for the United Nations and the sovereign countries of the world to denounce this illegal colonial relationship that subordinates residents of Puerto Rico to the will of the US Congress where they have no voting representatives. The right to self-determination needs to be finally 
recognized to Puerto Rico and the remaining colonies listed and not listed in the UN roster of non-selfgoverning territories.

\section{Brief Conceptual Framework}

Chaturvedi clearly distinguishes colonialism and neocolonialism as two forms of imperialism - simply understood as the control of one country over another country.

This can take the form of colonialism, the attempt to establish overt political control and jurisdiction over another country; neo-colonialism, control exercised through economic domination; or cultural imperialism, the destruction or weakening of an indigenous culture and the imposition of an alien one. (Chaturvedi 2006, p. 143)

Kohn and Reddy (2017), on the other hand, argues that individuals erroneously treat imperialism and colonialism as synonyms because of the shared implication of political and economic control of the imperial/colonial power over a dependent territory. These two researchers define colonialism as the domination of one people to another via subjugation, which involves the transfer of population to the colony as permanent settlers. However, imperialism refers to the exercise of power of one country over another through sovereignty, settlement, or indirect mechanisms of control.

Colonialism is understood in this article as a system of domination and hegemonic relationship involving a territorial control of an indigenous or native majority over by a foreign minority (Osterhammel 1997). A colony is a non-self-governing territory subject to the sovereignty of a foreign country.

Nkrumah argues that imperialism moved into a new stage, from colonialism into neocolonialism, in the aftermath of the Second World War. Under neocolonialism "the subordinate state is, in theory, independent and has all the outward trappings of international sovereignty. In reality, its economic system and thus its political policy is directed from outside" (in Higginbottom 2016, p. 553; Nkrumah 2002, p. ix).

\section{The Historical Context of Colonialism in Puerto Rico}

November 19, 1493, is observed in Puerto Rico as the day Christopher Columbus "discovered" Boriquén the indigenous name used by the Taíno people to identify the archipelago of Puerto Rico - on the second trip of the conquest. However, Brau (1983) argues this first stop was a strategic one - to collect water and reorganize ships in their way to Hispaniola - and does not involve the colonization of the territory and the indigenous people living in the archipelago. In 1505, the Spanish crown granted a capitulation to Vicente Yañez Pinzón to colonize "San Juan de Boriquén” which was later officially named Puerto Rico (Moscoso and González Vales 2012, p. 93). Juan Ponce de León was in charge of the colonization of Puerto Rico. A first exploration voyage was conducted in 1506, where the conquistadores learned about the social structure, political organization, and the geography of the territory (Moscoso and González Vales 2012, p. 94). Two 
years later, in 1508, Ponce de León initiated the conquest in the chiefdom of the principal cacique Agüeybana - located nowadays in the southwestern town of Guánica (Blanco 1973).

For almost four centuries, Puerto Rico was a Spanish colony. The Taíno indigenous population was decimated. Estimates vary considerably, but Blanco (1973) refers to a reduction from around 5,500 in the early days of the conquest to less than 4,000 in $1515,1,148$ in 1531 , and 70 in 1544 . Previous estimates do not consider hidden communities of Taínos and were corrected in the late eighteenth century to around 2000 "pure indigenous" by the mid-sixteenth century (1973, p. 13). A Captain General - a military title - ruled internally Puerto Rico since 1580, which "could do pretty much as he pleased" (Trias Monge 1997, p. 6). However, the Caribbean archipelago was part of the viceroyship of New Spain - nowadays Mexico.

Puerto Ricans had to wait until the end of the nineteenth century for their first legislature. Even though mayors were de jure elected positions, only five of them were de facto elected by the end of the nineteenth century (Trias Monge 1997, p. 7). However, as Trías Monge argues, in the short-lived Spanish 1812 Constitution, Puerto Rico and the rest of the Spanish colonies officially became Spanish provinces with full voting representation in the Spanish Cortes (Parliament). Right to universal male suffrage and Spanish citizenship was imposed to free Puerto Ricans, and the extension of human rights became a reality for the first time. These freedoms and rights only lasted for 2 years, and with some intermissions, the Spanish Monarchy ruled Puerto Rico with absolute power until 1869. Puerto Rico regained the right to send representatives to the Spanish Cortes in 1869, along with the Spanish citizenship, and the recognition as a Diputación Provincial with a local parliament in 1876.

In the first chapter of the Economic History of Puerto Rico, Dietz (2002) summarizes the economics of the Spanish colonial rule over Puerto Rico. The first three centuries resulted in a limited and unequal economic development. An eighteenth-century document highlights Puerto Rico as the poorest territory of Spanish America (2002, p. 27). Puerto Rico's national economy began to consolidate behind the sugar industry in the late eighteenth century and especially during the nineteenth century. The economic interest of the US over Puerto Rico was clear since the nineteenth century. By 1830, $49 \%$ of Puerto Rican exports went to the US versus $6.8 \%$ to Spain - and 27.2\% of Puerto Rican imports came from the US (Steward 1956, p. 52). According to Dietz (2002), the nineteenth century brought a relative economic and social progress to Puerto Rico. Although Spain tried to limit the industrialization of the archipelago with the prohibition of imports and credit restrictions, the manufacturing sector grew, especially in sugar, rum, and cigars. Nonetheless, Dietz argues that the basis of the Puerto Rican economy continued to be primitive agriculture (2002, p. 33).

One of the paramount political achievements in the Spanish colonial era was the Autonomic Charter decree on November 25, 1897. It is considered as the "most advanced document of any Caribbean colony until after the Second World War" due to the degree of self-government granted to Puerto Rico (Trias Monge 1997, p. 13). What does the Autonomic Charter granted to Puerto Rico? First a local parliament of two chambers. The lower chamber was elected entirely by universal suffrage. 
Meanwhile, eight of the members of the higher chamber were elected by universal suffrage, and the Governor appointed the remaining seven. However, the local Parliament was not able to sponsor a bill on his own, and the Spanish King was able to veto any local law.

Nonetheless, the degree of self-government with the 1897 Autonomic Charter was higher than the actual level in several aspects. The most significant concession from Spain to Puerto Rico was that only the Insular Parliament had the power to request an amendment of the Autonomic Charter. On the contrary, and as this chapter discusses below, Puerto Rico is nowadays subject to the plenary powers of the US Congress, which legislate directly on Puerto Rico without any Puerto Rican voting members in the US Congress.

The US colonial era started in 1898. McKelvey (2016) argues that the fear of economic crises caused by overproduction is the origin of US imperialist policies. This fear gave rise to a new US expansionist foreign policy. The "goal was to find new markets outside the US for the US manufactured and agricultural products" (2016, p. 756). US "capitalists hoped to solve the imbalance of production of demand through expansion into foreign markets" (Olson 2016, p. 771). The US government focused their efforts in Hawaii, Cuba, Guam, Puerto Rico, and the Philippines because of their strategic geopolitical locations in the Pacific and the Caribbean.

The Cuban-Hispanic-American War in 1898 is considered the first practical implementation of US imperialism, although the US justified the colonial character of their military interventions and territorial acquisitions in a new manifest destiny to expand the values of democracy, justice, and liberty to overseas territories (Arboleya 2008). The US bombed Puerto Rico and later invaded the Caribbean archipelago on July 25, 1898, during the Cuban-Hispanic-American War (González Vales and Luque 2012). Since then, Puerto Rico has been a colonial possession of the US.

Colonies are valued possessions. The US considered Puerto Rico, the Philippines, and other islands in the Caribbean and the Pacific as useful ports and coaling stations for US trading ships in their road to the Asian markets (Olson 2016). The idea of a Central American isthmus - which was later materialized with the independence of Panama and the construction of the Panama Canal - required possessions in the Caribbean for security reasons. Puerto Rico and the US Virgin Islands - former Danish possessions - fulfilled the geopolitical purposes for the establishment of US military bases. The US did not see most of these overseas possessions as potential future full members in the US Federation (McCormick 1967). The Insular Cases in the US Supreme Court established that Puerto Rico was a US possession and not part of the US. The US made a clear distinction between territories destined to become part of the US Federation (e.g., Hawaii, Alaska) and those territories that would remain as unincorporated territories (e.g., Puerto Rico, the Philippines, US Virgin Islands, American Samoa, Guam, and Northern Marian Islands) (Cruz-Martinez 2017c). US Senator Foraker told the US Congress in 1900: 
We understand that the effect of the treaty [of Paris] was to put the United States into possession of Puerto Rico. We do not understand it was intended or expected to make them a State or to do that which entitled them to be called even a Territory. We understand (...) that we have a right to legislate with respect to them as we may see fit. (Congressional Record 1900; in Fernandez 1996, p. 9)

During the first years of the US colonial era, a military authoritarian government appointed by the US ruled Puerto Rico. The military governors dissolved the elected Puerto Rican Council of Ministers, threatened newspapers who demanded the end of military rule, appointed US citizens at the head of the insular police force, and suspended civil authority by dismissing mayors and local councilmen (Trias Monge 1997). The US Secretary of War was officially in charge of Puerto Rico - and it remained for several decades before passing the colony to the jurisdiction of the US House Committee on Natural Resources. This could be understood as if Puerto Rico was first valued as a military possession and now as a natural resource of the US.

The US transformed the Puerto Rican economy from a "diversified agricultural export economy (...) to a monoculture economy that was almost exclusively dependent on sugar production for US market" (Caban 1999, p. 70). Quintero Rivera (1980) argues that the monetary measures by the US during the first years of colonization were aimed at establishing the hegemony of US sugar corporations by replacing domestic producers and landowners (i.e., hacendados). Besides the use of tariffs with Spain and the rest of Europe, US President Mckinley decreed the use of US dollars and devalued the Puerto Rican currency to an exchange rate of 60\% against the US dollar (Caban 1999, p. 75). The forced devaluation aggravated the situation of the local bourgeoisie by reducing the value of their savings and assets and making new loans relatively more expensive.

Puerto Ricans had to wait until May 1900 to have a civil government back in power, although not democratically elected. The 1900 Foraker Act was the first organic act imposed by the US. The Foraker Act implemented the Resident Commissioner (i.e., the nonvoting Puerto Rican member in US Congress); a limited number of residents in Puerto Rico obtained voting rights to elect the 35 members of the House of Delegates (i.e., lower chamber), while the US President appointed the Executive Council (i.e., higher chamber) and the governor (i.e., head of government). The US Congress had the power to annul any law approved by the insular legislature. Directly or indirectly, all members of the judiciary system were appointed by the US. All US laws were extended to Puerto Rico, without the previous consent of Puerto Ricans.

US colonialism took away several rights to Puerto Ricans. Residents in the archipelago lost equal citizenship to the metropolis, representation in the legislature of the metropolis, right to universal male suffrage, a locally elected parliament, the right to establish its tariffs, and the right to enter into commercial treaties with foreign countries. As Trias Monge (1997, p. 43) eloquently pointed out, the most significant loss was "the right to government by consent of the governed." The 1897 Autonomic Charter was subject to the constituents of Puerto Rico and was only amendable at the request of the elected local parliament. On the contrary, since the 
US occupation until nowadays, Puerto Rico remains subject to the unilateral will of the US Congress under the plenary powers of the Territorial Clause of the US Constitution. The supposedly temporary act to provide Puerto Rico with a civil government has never been repealed, and some of its sections are still in place nowadays as the Federal Relations Act.

In 1917 the US enacted the second organic law for Puerto Rico: the Jones Act. The most significant modification was the imposition of US citizenship to all Puerto Rican citizens in the eve of the First World War, although there were discussions around this issue since at least 1910 (See Vazquez-Lazo 2017). Caban (2002) argues that the imposition of the US citizenship aimed to silence the growing expressions for sovereignty and to accentuate the interest of the US to retain Puerto Rico as a possession for an indefinite time. A local Senate replaced the Executive Council, although the effective decision-making power remained in the US-appointed governor. The Jones Act did not alter the US Congress's plenary powers over Puerto Rico, and the archipelago remained under the jurisdiction of the War Department. A bill of rights was included in the Jones Act, although US constitutional protection was not extended to the colony.

US agricultural trusts turned the archipelago into a monoculture plantation economy (Dietz 2002). Following the trickle-down ideology, Neveling (2016) argues US capital investors asked for political and financial support from the insular Caribbean government (e.g., tax breaks) because, according to investors, they were bringing profitable investment and employment to Puerto Rico. In 1947, Puerto Rico became the first export processing zone - also known as a special economic zone or free-trade zone (Neveling 2016) (See Neveling 2015, 2017 for an in depth analysis of the role of Puerto Rico in the formation of global export processing zones).

The tax break scheme used by the US Congress was one of the essential ingredients of Puerto Rico's longtime "industrialization by invitation" model. The US Congress decided to industrialize Puerto Rico by attracting US capital and creating a kind of tax haven with multiple federal and national tax exemptions. The US Congress decided to take away the fiscal benefits of section 936 in 1996. In 2006 section 936 of the US tax code was eliminated entirely, the tax incentive disappeared, US firms stopped being able to relocate the income generated by subsidiaries in Puerto Rico as tax-free dividends, and the entire model collapsed (Cruz Martinez 2017). Caraballo-Cueto and Lara (2018) argue that the removal of section 939 "set the stage for the worst depression in the Puerto Rican economy in more than 100 years" by igniting a deindustrialization process with a sharp decrease in manufacturing employment, which led to an increase in government borrowing. The archipelago entered into a spiral of economic, fiscal, and debt crises, and later accentuated by the global financial crisis - colloquially known as the Great Recession - and the subsequent destruction of the Hurricanes Irma and Maria (see the special issue by Cruz-Martínez et al. ( 2018) and Bonilla and Lebrón (2019) to explore the causes and consequences of the hurricanes).

In the aftermath of the Second World War and under the international agenda to eradicate colonialism, the US Congress passed two bills with relevant ramifications for Puerto Rico. The Elective Governor Act of 
1947 allowed Puerto Ricans to elect the head of government for the first time. Public Law 81-600 established the procedures for an elective government with local autonomy although without sovereignty (i.e., still under the plenary powers of the US Congress). Public Law 81-600 allowed Puerto Ricans to enact a local Constitution. Nonetheless, US Congress modified it before the final approval. The US used Public Law 81600 and the 1952 Constitution, which officially established the Commonwealth of Puerto Rico - or Free Associated State as it is known in Puerto Rico - to take Puerto Rico out of the UN list of non-self-governing territories. However, the new invention (i.e., the Free Associated State status) kept Puerto Rico a US colony. David M. Helfeld eloquently argued that:

Though the formal title [of Puerto Rico's status] has been changed, in constitutional theory Puerto Rico remains a territory. This means that the [US] Congress continues to possess plenary (...) authority over Puerto Rico. (...) Congress may repeal Public Law 600, annul the Constitution of Puerto Rico or veto any insular legislation which it deems unwise or improper. (...) the compact between Puerto Rico and the Congress may be unilaterally altered by the Congress. (...) Constitutionally, the most meaningful view of the Puerto Rican Constitution is that it is a statute of the Congress which involves a partial and non-permanent abdication of Congress' territorial power. (Statham Jr. 2002, pp. 34-35)

Following Torruella (2018), the establishment of the 1952 Constitution in Puerto Rico could be considered as one of the five experiments in US colonial governance of Puerto Rico. The authoritarian military government during the first years of US colonialism was the first experiment. Later, the Foraker Act started the second colonial governance experiment (1900-1917). The third period began with the 1917 Jones Act and lasted until the 1952 Constitution. With the Puerto Rican Constitution and the status as a Free Associated State, the Caribbean archipelago began the fourth long experiment of US colonial governance. The fifth period began when the US Congress approved the federal law "Puerto Rico Oversight, Management, and Economic Stability Act" (PROMESA) (US Congress 2016) in June 2016. The US Congress took away the fiscal autonomy of Puerto Rico and transferred it to an unelected Fiscal Control Board in charge of Puerto Rico's finance since then. In exchange, Puerto Rico was allowed to enter into a bankruptcy-like process to restructure the US\$72 billion dollars in debt and over US\$40bn in unfunded pension obligations. It is of utmost importance to notice that until 1984 Puerto Rico was allowed to declare bankruptcy under chapter 9 of the US bankruptcy code. Since then the US Congress denied the archipelago of that right.

\section{Why and Who Consider Puerto Rico a Colony?}

César Ayala and Rafael Bernabe imply that the colonization of Puerto Rico, Guam, and the Philippines in 1898 inaugurated an era of US neocolonialism in the Caribbean and Central American region. "Cuba, Panama, the Dominican Republic, Haiti and other formally independent republics became de facto U.S. protectorates" (Ayala and Bernabe 2009, p. 7). However, the three branches of the US government have confirmed the colonial status of Puerto Rico. This section briefly addresses some of the most significant 
decisions by each of the three branches. See Puerto Rico Report (2011) for an extensive and updated list on the national and international statements over Puerto Rico's colonial status.

\section{Judicial Power}

The US Supreme Court was the first to confirm the colonial status of Puerto Rico. From 1901 to 1905, the US Supreme Court in the well-known and studied Insular Cases cleared out some controversies. The Supreme Court was debating whether to allow the US to become an empire and break the tradition of the eventual admission of territories as states of the US Federation or to condemn colonialism. The Supreme Court confirmed that the US could have two types of territories (i.e., incorporated and unincorporated). The former is considered part of the US, and the unincorporated territories are US possessions and not part of the US Federation. Maybe the most important decision from the US Supreme Court to understand colonialism in Puerto Rico is the 1901 Downes versus Bidwell. Because of a dispute over imports of oranges from Puerto Rico to New York, the US Supreme Court explicitly confirms that Puerto Rico is not and has never been part of the US in the domestic sense, the US Congress has plenary powers over Puerto Rico, and Puerto Rico is indeed a colony of the US. Therefore, the Supreme Court of the US legally allowed for the formation of a US colonial empire. The US was allowed to hold territorial possessions for an indefinite amount of time and to discriminate colonies against states of the US. In the Supreme Court own words:

The result of what has been said is that, while in an international sense Porto Rico was not a foreign country, since it was subject to the sovereignty of and was owned by the United States, it was foreign to the United States in a domestic sense, because the island had not been incorporated into the United States, but was merely appurtenant thereto as a possession. (US Supreme Court 1901, p. 182)

Later in 1922, the US Supreme Court confirmed in the Balzac case that the fact that Puerto Ricans are US citizens do not make Puerto Rico part of the US (US Supreme Court 1922). In a second circuit case, Romeu versus Cohen confirmed that a US citizen residing in Puerto Rico does not have the same voting rights as a US citizen living in any of the 50 states of the federation (US Court of Appeals 2001).

The US Supreme Court recently made a significant decision in 2016: Puerto Rico versus Sanchez Valle (US Supreme Court 2016). Two individuals were accused of selling a gun to an undercover policeman. Both Puerto Rico and US courts indicted them. They pleaded guilty to the US federal charges and asked for a dismissal of these charges in Puerto Rico on double jeopardy grounds (i.e., a person cannot be prosecuted twice for the same crime in the same sovereignty). In the US judicial system, a state has its sovereignty different from the US federal government. Therefore, an individual can be prosecuted for the same crime in the US federal court and a US State Court. However, the US Supreme Court decided on a 6-2 decision that 
"Puerto Rico does not have independent authority to prosecute someone for the same crime that has been charged in federal court. The argument appears to diminish the constitutional stature that the Puerto Rican government thought it has had for nearly seven decades" (Denniston 2016). Therefore, this decision confirms that Puerto Rico lacks judicial sovereignty because it is entirely subordinated to the US Congress under the US Constitution's Territorial Clause.

Finally, in Harris versus Rosario, the US Supreme Court decided that the US Congress can make all requiring "rules and regulations respecting the territory (...) belonging to the United States" (US Supreme Court 1980). Therefore, Puerto Rico could be treated differently from any actual state of the US Federation as long as the US Congress considers there is a rational basis for this discrimination. In Torres versus Puerto Rico, the US Supreme Court confirmed that Puerto Rico has no sovereign authority over its borders, contrariwise US federal officers control borders and customs (US Supreme Court 1979).

\section{Executive Power}

In the year 2000, US President Bill Clinton created a workgroup called “Task Force on Puerto Rico's status," which intended to assess the situation of the status of Puerto Rico. In 2005, under the administration of George W. Bush, the Task Force confirmed that Puerto Rico is a territory subject to the authority of Congress under the Territorial Clause. It was noted that the US Congress could revise or revoke the current status at its discretion and legislate directly on local issues. Furthermore, the report noted that Congress had the power to grant independence to Puerto Rico or even transfer it to another nation-state. The Task Force published two additional reports in 2007 and 2011. The latter set a deadline to solve the colonial status of the archipelago by 2012. At the time of writing, no concrete progress to decolonize Puerto Rico has been made.

US Department of Justice confirmed the territorial status of Puerto Rico and argued that the archipelago could overcome this status either by incorporation to the US Federation or via sovereignty (US Department of Justice 2015). Former Secretary of State Colin Powell confirmed in 2003 Puerto Rico's lack of sovereignty to conduct foreign relations without the consent of the US (Powell 2003). According to Raben (2001), Assistant Attorney General to former President Bill Clinton, the US Congress is entirely vested of legislative powers by the Territorial Clause of the US Constitution.

\section{Legislative Power}

In 2016, a US Congressional Task Force confirmed that Puerto Rico, along with Guam, American Samoa, US Virgin Islands, and Northern Marian Islands, are unincorporated territories of the US (Duffy et al. 2016). Therefore, the colonial status of the five territories was confirmed as all are subject to the US Congress's plenary powers and can be discriminated by the US Congress against US states. The best example is the second-class coverage provided by the US government in social welfare programs destined for its colonies. For example, in October 2018 the US confirmed their power to discriminate against US citizens residing in Puerto Rico by not extending the Supplemental Security Income Benefits - a targeted social assistance cash 
transfer program for income poor individuals (Figueroa Cancel 2018). See Duffy et al. (2016, pp. 95-111) for a list of US federal programs under which Puerto Rico receives a discriminatory treatment in comparison to the US states.

In a Congressional Research report from 2008, the US Congress confirmed that the status of Puerto Rico did not change with the 1952 local Constitution because US Congress did not cede its plenary authority over the archipelago (Garrett 2011). US Congress reminded us that not all constitutional rights are extended to residents of the territories. Puerto Rico remains a colony of the US subject to the Territorial Clause of the US Constitution. US Congress has the power to enact legislation on internal matters of Puerto Rico, as it recently did with the approval of the Puerto Rico Oversight, Management, and Economic Stability Act (PROMESA) (US Congress 2016).

The US Congress could be considered as an "almighty" institution regarding its power over Puerto Rico. If US Congress “chose to alter Puerto Rico's political status, it could do so through statute. Ultimately, the Territory Clause of the U.S. Constitution grants Congress broad discretion over Puerto Rico and other territories" (Garrett 2017, p. s1). The power of the Territorial Clause was also confirmed in a 1997 General Accounting Office report (GAO 1997).

\section{Puerto Rican and International Actors}

Local Puerto Rican politicians from all three main political parties have confirmed and condemned the colonial status of Puerto Rico. Former pro-statehood governor, Carlos Romero Barceló, equated the official territorial status to the more straightforward and widely known concept of the colony. "In constitutional terms, U.S. terms, [Puerto Rico] is a territory. In international terms, it is a colony. But it is the same thing to me, territory, colony, what the heck" (Fernandez 1996, p. 229).

A recent paper by Developments in the Law (2017) published in the Harvard Law Review confirmed that Puerto Rico is a non-self-governing territory under international law. In 1953 the United Nations wrongly misjudged the level of internal autonomy of Puerto Rico under the 1952 Constitution and took the archipelago out of the list of recognized colonies. This publication argues that Puerto Rico does not meet the United Nations standards of self-governance because (1) the PROMESA Oversight Board -colloquially known in Puerto Rico as the Fiscal Control Board - has extensive powers incompatible with the standards of selfgovernance and (2) recent judicial decisions confirmed the power of the US federal government to impose capital punishment even though it was abolished internally in Puerto Rico since 1929.

Since 1972, the United Nations Decolonization Committee has approved 37 resolutions demanding the inalienable right of the people of Puerto Rico to self-determination and independence according to the 1514 resolution from the UN General Assembly. The US Congressional Research Service acknowledged that: "Although the Constitution of 1952 provides for self-government by Puerto Ricans, US Congress ceded none of its own plenary authority over the islands" (Garrett 2011). This makes the 1953 approval of UN Resolution 
748, which removed Puerto Rico from the list of non-self-governing territories, seems a little disingenuous. The last resolution by the UN Decolonization Committee was approved by consensus on June 2018 and requested the US to promote a self-determination process in Puerto Rico that indeed guarantees a noncolonial status. What are the internationally recognized options to decolonize Puerto Rico once and for all after over five centuries of colonialism?

\section{Options for Decolonizing Puerto Rico}

The United Nations recognizes three options for the decolonization of a non-self-governing territory. The first one is the emergence of the colony as a sovereign independent state, which has historically been the traditional option for decolonizing a territory. The second option is a free association with an independent state, and the third option is the integration within an independent state. The actual status - the Free Associated State - is not recognized under international law as a self-governing status. The status quo perpetuates colonial power of the US over Puerto Rico because the archipelago remains subordinated to the powers of the US Congress and subject to the Territory Clause of the US Constitution. This section briefly addresses the non-colonial options for decolonizing Puerto Rico.

\section{Option 1: Independence}

"Independentistas" - supporters for Puerto Rico's independence - have based their arguments for sovereignty on national identity and economic opportunities. Their first argument is simple; Puerto Rico is a Latin American nation with their language and traditions. Therefore, in order to maintain the Puerto Rican identity, the archipelago must not be annexed to the US as the 51st state.

The economic argument is based on political power. Pedro Albizu Campos - one of the leading figures for independence in the twentieth century - argued that "economic development was inextricably linked to, and based on, political power" (Fernandez 1996, p. 112). The political power would be used - according to the Independence Party - to integrate Puerto Rico in the global economy by creating bilateral and multilateral agreements, joining international organizations and regional blocks (e.g., CARICOM, UN, CELAC), and by being able to use the monetary policy to control inflation and promote investment (PIP 2012). In addition, imported goods are expected to become up to $30 \%$ cheaper with the abolition of the Cabotage Laws that oblige Puerto Rico to use the US marine merchant to transport goods between the archipelago and the US (EFE 2014) (see Valentín-Mari 2014 for a detailed analysis of the Cabotage Laws and the impact on the economy of Puerto Rico). The Cabotage Laws (i.e., the Jones Act of 1920) have had an estimated negative impact on the Puerto Rican economy of US\$ 29 billion during 1970-2012 (Telesur 2015).

Advocates for independence argue that electoral support for independence has been decimated during the last century for the repression and persecution of "independentistas" by the insular and US governments and by manufacturing consent in the Puerto Rican psique equalizing independence with poverty and communism 
(Denis 2015). According to the former president of the Independence Party, the government was able to indoctrinate political and economic fears to independence (Berríos Martínez 1983).

\section{Option 2: Free Association with an Independent State}

Free association is the second option for the decolonization of non-sovereign territories under international law. If Puerto Rico takes this path, it will become a sovereign state with a free and voluntary association with the US.

The main difference with the actual status of Puerto Rico is that free association does not subordinate the archipelago to the US Congress. This is instead supposed to be a relationship between sovereign states, where they establish an agreement that legally connects them in designated political, economic, military, monetary, or other areas (see below for a critical argument from Ramón Grosfoguel). The Republic of Palau, the Federated States of Micronesia, and the Republic of the Marshall Islands have established a free association agreement with the US. The US provides economic and programmatic assistance, and the Pacific Islands provide military bases for the US. Also, both benefit from a free movement of people clause (Berríos Martínez et al. 2010, p. 172). Niue and Cook Islands are also examples of countries with a free associated relationship, in this case with New Zealand.

According to the "Movimiento Union Soberanista" (MUS) - political party in favor of the free association there are numerous benefits for this non-territorial option. Residents in Puerto Rico would benefit from a dual citizenship (the US and Puerto Rico), free movements of people and goods between the US and Puerto Rico, and actual beneficiaries of the US social security benefits would be able to continue receiving these contributory benefits. Also, the MUS argues that Puerto Rico would be able to claim economic reparations for the damages suffered during colonial subordination and for the violation of human rights (MUS 2016). The free association compact would be signed by both sovereign states and could be terminated - after due procedures - unilaterally by any party.

\section{Option 3: Integration Within an Independent State}

Integration of a non-sovereign territory (i.e., Puerto Rico) into a sovereign state (i.e., the USA) is the third decolonizing option recognized by the United Nations. After integration, peoples of both territories should have equal rights and responsibilities without distinction nor discrimination, equal citizenship, and equal opportunities for political participation in all branches of government.

Advocates of statehood argue that this is the only non-colonial status that guarantees US citizenship and a permanent status with the US. Moreover, Puerto Rico would gain representation in US Congress and the right to vote for the head of state. There would be equal access to social assistance and social security benefits, whereas now Puerto Ricans contribute to Medicare but are not entitled to receive Supplemental Security 
Income in older age. Statehood advocates also argue that the political stability of the US will bring more inward investment.

US Congress would have to accept the incorporation of a Spanish-speaking Latin American country during the xenophobic administration of Donald Trump. Not only would the new State come with an unsustainable debt of around US\$72 billion plus over US\$40 billion in unfunded pension obligations, but it would also have more representation in Congress than several less densely populated states. The US Government Accountability Office highlighted the high cost of statehood for Puerto Rico, adding US $\$ 2.3$ billion in new federal taxes (Brito 2014; GAO 2014).

A 2016 public opinion report shows that support for Puerto Rico's statehood in the USA has risen from 35\% in 2013 to 40\% in February 2017 (Rasmussen Reports 2017). In addition, 39\% disagree that Puerto Rico should become a state of the union and $21 \%$ are undecided. If we consider these numbers to be representative of the opinion of congressional representatives, there is still a long road to have an absolute majority favoring the incorporation of Puerto Rico. However, what is the desire of the residents in Puerto Rico toward the political status options and its relationship with the US?

\section{Referendums}

Trias Monge (1997, p. 12) duly notes the similarities of the public opinion in Puerto Rico and political organization in the late nineteenth century with the present, where three groups are identified in the archipelago: annexationists - formerly to Spain and nowadays to the USA - pro-sovereignty, and status quo devotees.

Puerto Rican governments have held five referendums on political status since 1967, but the US Congress has endorsed none of these despite being the only stakeholder with the constitutional power to resolve the colonial status of Puerto Rico. The options to date are presented in Table 1.

The Free Associated State option was favored in the first two referendums (1967 and 1993). In 1998 the prostatehood New Progressive Party boldly added an extra option in the hope of dividing status quo voters, but ultimately it was the "none of the above" option which won out with 50.3\%. In 2012 there were two ballots. In the first ballot, most electors voted to change the current territorial status, and in the second ballot, statehood was the preferred non-colonial option, though it received less than 50\% of the ballots. 
Table 1: Options in the five status referendums to date

\begin{tabular}{|c|c|c|}
\hline $\begin{array}{l}\text { Option in the previous } \\
\text { ballots }\end{array}$ & Description & Colonial or non-colonial status? \\
\hline $\begin{array}{c}\text { Free Associated } \\
\text { State } \\
\text { (commonwealth) }\end{array}$ & $\begin{array}{l}\text { Mandate to develop the relationship between the } \\
\text { USA and Puerto Rico to the maximum of self- } \\
\text { government compatible with the common defense, } \\
\text { the common market, the common currency, and the } \\
\text { indissoluble bond of the US citizenship. Supporters } \\
\text { of status quo portray it as an enhanced Free } \\
\text { Associated State }\end{array}$ & $\begin{array}{l}\text { Colonial; Puerto Rico gains } \\
\text { autonomy but not sovereignty. It } \\
\text { remains under the Territorial } \\
\text { Clause of the US Constitution. } \\
\text { International law does not } \\
\text { recognize it as non-colonial }\end{array}$ \\
\hline Statehood & $\begin{array}{l}\text { A vote for the statehood is a mandate to claim the } \\
\text { entry of Puerto Rico as a state of the union (US) }\end{array}$ & $\begin{array}{l}\text { Non-colonial; Puerto Rico will } \\
\text { join the USA with the same rights } \\
\text { and duties as all } 50 \text { states }\end{array}$ \\
\hline Independence & $\begin{array}{l}\text { A vote for the independence is a mandate to claim } \\
\text { the creation of a new sovereign state }\end{array}$ & $\begin{array}{l}\text { Non-colonial; Puerto Rico will } \\
\text { become a sovereign state }\end{array}$ \\
\hline $\begin{array}{l}\text { Territorial } \\
\text { commonwealth }\end{array}$ & $\begin{array}{l}\text { Status quo; Puerto Rico will remain with the actual } \\
\text { territorial (colonial) status }\end{array}$ & $\begin{array}{l}\text { Colonial; Puerto Rico will remain } \\
\text { under the Territorial Clause of the } \\
\text { US Constitution. }\end{array}$ \\
\hline $\begin{array}{l}\text { Free Association / } \\
\text { Sovereign Free } \\
\text { Associated State }\end{array}$ & $\begin{array}{c}\text { Mandate to become a sovereign state with a free and } \\
\text { voluntary association with the US }\end{array}$ & $\begin{array}{l}\text { Non-colonial; Puerto Rico will } \\
\text { become a sovereign state }\end{array}$ \\
\hline
\end{tabular}

The last referendum held in 2017 was designed to have only non-colonial options recognized by international law in the ballot. However, the US State Department demanded the inclusion of the status quo option. The intromission of the USA on the internal affairs of Puerto Rico provoked a call to boycott the referendum. The actual leading opposition party and pro-status quo supporter (i.e., Popular Democratic Party), the Independence Party, and a multiparty coalition supporting free association opted not to participate in the referendum. The Popular Democratic Party argued that the status quo option described in the ballot undermines their view of an enhanced Free Associated State. Supporters of Independence and free association, meanwhile, refuse to participate in a referendum that includes an extension of the current status.

Once again, the US Congress has not recognized the results of the fifth referendum. With a record high $76.8 \%$ of abstention, it is reasonable not to consider these results to be the will of the people of Puerto Rico. Nonetheless, Puerto Rico should learn from the disastrous experience of the Venezuelan opposition with the abstention in the 2005 legislative elections, which allowed the former President Hugo Chavez to take control of a large part of the government. Therefore, abstentionism might not be the most effective solution.

This is why the US Congress should sit down with social movements, political parties, and other groups of the Puerto Rican society to establish a set of non-colonial options for inclusion in a binding referendum. The second alternative is to call a national constituent assembly where the residents in Puerto Rico could establish a non-colonial set of options to be validated later at a referendum (see Pérez Soler 2016). See Table 2 for the results of every referendum since 1967. 
Table 2: Results of the five referendums on the political status of Puerto Rico

Referendum 1967

\begin{tabular}{|c|c|c|}
\hline & Votes & Per cent \\
\hline Free Associated State (status-quo) & 425.132 & 60,11 \\
\hline Statehood & 274.312 & 38,78 \\
\hline Independence & 4.248 & 0,60 \\
\hline Null votes & 3.601 & 0,51 \\
\hline \multicolumn{3}{|c|}{$\begin{array}{l}\text { Table 2: Results of the five referendums on the political status of Puerto Rico (cont.) } \\
\text { Referendum } \mathbf{1 9 9 3}\end{array}$} \\
\hline & Votes & Per cent \\
\hline Free Associated State (status-quo) & 826.326 & 48,58 \\
\hline Statehood & 788.296 & 46,34 \\
\hline Independence & 75.620 & 4,45 \\
\hline Null votes & 6.549 & 0,39 \\
\hline Blank votes & 4.199 & 0,25 \\
\hline \multicolumn{3}{|l|}{ Referendum 1998} \\
\hline & Votes & Per cent \\
\hline None of the above & 787.900 & 50,30 \\
\hline Statehood & 728.157 & 46,49 \\
\hline Independence & 39.838 & 2,54 \\
\hline Free association & 4.536 & 0,29 \\
\hline Territorial commonwealth & 993 & 0,06 \\
\hline Null votes & 2.956 & 0,19 \\
\hline Blank votes & 1.890 & 0,12 \\
\hline Referendum 2012 & & \\
\hline
\end{tabular}

Do you agree that Puerto Rico should continue to have its present form of territorial status?

$\begin{array}{lll} & \text { Votes } & \text { Per cent } \\ \text { No } & 970.910 & 51,67 \\ \text { Yes } & 828.077 & 44,07 \\ \text { Blank votes } & 67.267 & 3,58 \\ \text { Null votes } & 12.948 & 0,69\end{array}$

\section{Second ballot}

Which of the non-territorial options would you prefer?

Statehood

Blank votes

Sovereign Free Associated State

Independence

Null votes

Referendum 2017

$\begin{array}{ll}\text { Votes } & \text { Per cent } \\ 834.191 & 44,39 \\ 498.604 & 26,53 \\ 454.768 & 24,20 \\ 74.895 & 3,99 \\ 16.744 & 0,89\end{array}$

Plebiscite for the immediate decolonization of Puerto Rico 
Source: Official results published by the Puerto Rico State Elections Commission

In January 2017, Jenniffer Gonzalez, the nonvoting US congressional representative for Puerto Rico, introduced the Puerto Rico Admission Act, which proposes January 3, 2025, as the date of incorporation if statehood was chosen in the last referendum (Gonzalez-Colon 2017). The bill was referred to the Subcommittee on Indian, Insular and Alaska Native Affairs on February 2017. The bill was never considered on the floor of US Congress.

The governor of Puerto Rico, Ricardo Rosselló, considers that because statehood won on June 11, 2017, he has the mandate to pursue the unilateral "Tennessee Plan" followed by Tennessee, Michigan, Iowa, California, Oregon, Kansas, and Alaska to become states of the USA (Garrett 2011). However, it is the US Congress who would first need to incorporate Puerto Rico and then admit it as a US state. This might be one of the reasons why the nonvoting US congressional representative for Puerto Rico introduced in June 2018 the Puerto Rico Admission Act of 2018 (i.e., a second bill on the admission of Puerto Rico as a state of the US Federation, with a transition period as an incorporated territory) (Gonzalez-Colon 2018). The bill has been largely ignored like the 2017 admission act and has not been considered in the US Congress floor, and the last action was on July 2018 where the Committee on Natural Resources referred it to the Subcommittee on Indian, Insular and Alaska Native Affairs. The lack of attention and serious consideration by the US Congress on this matter is not a novelty; US actions over the last century have shown disdain for the idea of ending colonialism in Puerto Rico. A Democratic Representative for Florida, Darren Soto, introduced the H.R.1965 Puerto Rico Admission Act in March 2019. The bill ask US Congress to incorporate Puerto Rico into the US federation as the 51st state 90 days after the measure becomes law without the need for a new referendum because it considers the boycotted and non-binding 2017 referendum results as valid. At the time of writing, the House Committee on Natural Resources has made no concrete action with this bill.

\section{Is Puerto Rico a Neocolony?}

Grosfoguel (2008) argues that the two forms of sovereignty recognized as non-colonial status by international law (i.e., independence and free association) will produce a neocolonial Puerto Rican republic. According to Grosfoguel, any of these two decolonial options would allow the US empire to take away the "rights that have been won through much sweat and blood" using a strategy of neocolonial recolonization. The romanticized argument by Grosfoguel implies that the social and welfare rights of the residents in Puerto Rico would not continue (or improve) with a free association or an independent state. However, there is no evidence on this matter. Grosfoguel might be referring to the US federal transfers to Puerto Rico, which as 
expected would be reduced. In 2014 Puerto Rico received 17 billion dollars in US federal transfers. However, we need to distinguish contributory benefits (i.e., benefits received as a result of tax payment or service provided) and granted benefits (i.e., benefits transferred without contributions or service). Almost $80 \%$ of US federal transfers to Puerto Rico in 2014 were contributory benefits, which residents of Puerto Rico receive after contributing and meeting the eligibility requirements (i.e., social security, Medicare, military pensions, among others). Residents in Puerto Rico contributed to these programs, and a sovereign Puerto Rico would necessarily receive a fund from the US to cover these welfare programs.

Grosfoguel argues for a radical statehood option as a decolonizing option for Puerto Rico. According to him, this will prevent Puerto Rico from becoming the new neocolony in the Caribbean of high-income countries. Moreover, he argues that statehood will introduce a Latin American country to the US empire, with full political rights and the power to transform it from the inside into "a truly democratic, anticapitalist, antipatriarchal and anti-imperialist society" (Grosfoguel 2008, p. 7).

Puerto Rico is a colony and not a neocolony of the US as several academics and news media has confirmed. However, as Grosfoguel contends, a sovereign resolution for the archipelago, either as independence or free association, enables the possibility of Puerto Rico becoming a new US neocolony. Why? A sovereign Puerto Rico would be out of the direct control of the US Congress under the Territorial Clause of the US Constitution. However, as it was argued above, Puerto Rico could become a neocolony of the US - like many others in the region - if the economic system and policy decisions in the archipelago are directed from Washington DC. With this knowledge in mind, politicians and leaders of a potential sovereign Puerto Rico would need to take this with extreme seriousness when - and if - the time comes.

\section{Conclusion}

This essay presented a historical context of colonialism in Puerto Rico under the Spanish Empire (15081898) and the US empire (1898-present). Puerto Rico is a colony of the USA for two principal reasons: (1) Puerto Rico is subjected to the plenary powers of the US Congress under the Territorial Clause of the US Constitution; (2) Puerto Rico does not have the right to government by consent of the governed because sovereignty does not lie on the people of Puerto Rico but on the US Congress, which can annul or modify the insular Constitution and legislation unilaterally (i.e., without the consent of the governed) and without any voting representation in the US Congress. The three branches of the US government have confirmed this colonial relationship, as well as Puerto Rican politicians and international organizations. However, up to this date, the US has not shown or accepted a concrete solution to end colonialism in the Caribbean archipelago. Finally, it is of utmost relevance to point out the colonial status of Puerto Rico rather than referring to it as a neocolony. Puerto Rico cannot be considered a neocolony of the US because the metropolis directly excercise its control over the archipelago.

\section{Cross-References}


Cold War and Latin America

De-colonisation and the Legacy of Imperialism

Distressed Debt Acquisition and Vulture Capitalists

Global Finance Capital and Third World Debt

Nicaragua and Contemporary American Imperialism

Taxation, Capital Flight, and Imperialism

Western Democracy Promotion and Imperialism

\section{References}

Arboleya, J. (2008). La revolución del Otro Mundo. Habana: Editorial de Ciencias Sociales.

Ayala, C. J., \& Bernabe, R. (2009). Puerto Rico in the American Century: A History since 1898. Chapel Hill: University of North Carolina Press.

Berríos Martínez, R. (1983). La independencia de Puerto Rico: razón y lucha San Juan: Editorial Línea.

Berríos Martínez, R., Martín García, F., \& Catalá Oliveras, F. (2010). Puerto Rico: Nación independiente, imperativo del Siglo XXI. Santo Domingo, República Dominicana: Editora CORRIPIO.

Blanco, T. (1973). Prontuatio Histórico de Puerto Rico. San Juan: Instituto de Cultura Puertorriqueña.

Bonilla, Y. \& Lebrón, M. (eds.) (2019) Aftershocks of Disaster: Puerto Rico Before and After the Storm. Chicago: Haymarket Books.

Brau, S. (1983). Historia de Puerto Rico. San Juan: Editorial Edil.

Brito, A. (2014). GAO Confirms Statehood Too Costly for Puerto Rico and the U.S. Huffington Post, 04 February, Retrieved from https:/www.huffingtonpost.com/adrian-brito/gao-confirms-statehoodto_b_5070172.html?ec_carp=7956232230648303006.

Caban, P. A. (1999). Constructing a Colonial People: Puerto Rico and the United States, 1898-1932. Boulder, CO: Westview Press.

Caban, P. A. (2002). Puerto Rico: State Formation in a Colonial Context. Caribbean Studies, 30(2), $170-215$.

Caraballo-Cueto, J. \& Lara, J. (2018). "From Deindustrialization to Indebtedness: The Case of Puerto Rico". Journal of Globalization and Development, Vol. 8, 2, p.1-11 
Chaturvedi, A. K. (2006). Academic's Dictionary of Political Science. New Delhi: Academic (India) Publishers.

Congressional Record. (1900). Senate, March 2, 1900, p. 2483.

Cruz Martinez, G. (2017) Will Puerto Rico Find A Way To Survive Its Debt Crisis?/Interviewer: N. P. Flannery. Forbes, June 1, Retrieved from: https://www.forbes.com/sites/nathanielparishflannery/2017/06/01/will-puerto-rico-find-a-way-to-surviveits-debt-crisis/ - 47bd54c25b90.

Cruz-Martinez, G. (2017a). The end of colonialism in Puerto Rico? Evaluating the options in the 2017 political status referendum. LSE LAC Blog. Retrieved from http://blogs.lse.ac.uk/latamcaribbean/2017/05/05/the-end-of-colonialism-in-puerto-rico-evaluating-theoptions-in-the-2017-political-status-referendum/.

Cruz-Martinez, G. (2017b). Produciendo Bienestar. Una mirada desde las Comunidades Marginadas en Puerto Rico. Madrid: Dykinson.

Cruz-Martínez, G., Fernández Arrigoitia, M., Ortiz Camacho, J., \& Román-Velazquez, P. (2018). The Making of Caribbean Not-so-Natural Disasters. Alternautas, 5(2), Retrieved from: http://www.alternautas.net.

Denis, N. A. (2015). War against all Puerto Ricans: Revolution and Terror in America's Colony. New York: Nation Books.

Denis, N. A. (2017). After a Century of American Citizenship, Puerto Ricans Have Little to Show for It. The Nation, 2 March, Retrieved from: https://www.thenation.com/article/after-a-century-of-americancitizenship-puerto-ricans-have-little-to-show-for-it/.

Denniston, L. (2016). Opinion analysis: Setback for Puerto Rico's independent powers. SCOTUSblog, 9 June, Retrieved from: http://www.scotusblog.com/2016/06/opinion-analysis-setback-for-puerto-ricosindependent-powers/.

Developments in the Law. (2017). The U.S. Territories - The International Place of Puerto Rico. Harvard Law Review, 130(6), 1616-1656.

Dietz, J. L. (2002). Historia económica de Puerto Rico. Rio Piedras: Ed. Huracán.

Duffy, S., MacArthur, T., Pierluisi, P., Velazquez, N., Hatch, O., Rubio, M., . . Nelson, B. (2016). Congressional Task Force on Economic Growth in Puerto Rico. Report to the House and Senate. 114th Congress, 20 December, Retrieved from: https://www.puertoricoreport.com/wp- 
content/uploads/2011/07/Congressional-Task-Force-on-Economic-Growth-in-Puerto-Rico-December-202016..pdf.

EFE. (2014). Ley de Cabotaje asfixia la economía de Puerto Rico, según estudios. Noticel. Retrieved from https://www.noticel.com/economia/ley-de-cabotaje-asfixia-la-economa-de-puerto-rico-segnestudios/610980495.

Fernandez, R. (1996). The disenchanted island. Puerto Rico and the United States in the Twentieth Century. Westport, CT: Praeger.

Figueroa Cancel, A. (2018). Estados Unidos reitera los poderes plenarios en caso sobre Seguro Social. El Nuevo Dia, 14 October, Retrieved https://www.elnuevodia.com/noticias/locales/nota/estadosunidosreiteralospoderesplenariosencasosobresegu rosocial-2452914/.

GAO. (1997). U.S. Insular Areas. Application of the U.S. Constitution. Report to the Chairman, Committee on Resources, House of Representatives, November(GAO/OGC-98-5), Retrieved from: https://www.gao.gov/archive/1998/og98005.pdf.

GAO. (2014). Puerto Rico: Information on How Statehood Would Potentially Affect Selected Federal Programs and Revenue Sources. GAO-14-31, 4 March, Retrieved from: https://www.gao.gov/products/GAO-14-31.

Garret, S. (2017). Political Status of Puerto Rico:Brief Background and Recent Developments for Congress. Congressional Research Service Report, R44721, June 12, Retrieved from: https://fas.org/sgp/crs/row/R44721.pdf.

Garrett, S. (2011). Political Status of Puerto Rico: Options for Congress Cogressional Research Service Report for Congress, 7-5700, RL32933, Retrieved from: https://fas.org/sgp/crs/row/RL32933.pdf.

González Vales, L. E., \& Luque, M. D. (2012). Historia de Puerto Rico (Vol. IV). Madrid: Consejo Superior de Investigaciones Científicas; Doce Calles.

Gonzalez-Colon, J. (2017). H.R.260 - Puerto Rico Admission Act. 115th Congress, https://www.congress.gov/bill/115th-congress/house-bill/260/text.

Gonzalez-Colon, J. (2018). H.R.6246 - Puerto Rico Admission Act of 2018. 115th Congress, https://www.congress.gov/bill/115th-congress/house-bill/6246/all-actions.

Grosfoguel, R. (2008). The Neocolonial Project of the United States in Puerto Rico. ReVista. Harvard Review of Latin America(Spring), 3-7. 
Higginbottom, A. P. (2016). Anti-Apartheid, Anti-Capitalism, and Anti-Imperialism: Liberation in South Africa. In I. Ness \& Z. Cope (Eds.), The Palgrave Encyclopedia of Imperialism and Anti-Imperialism (pp. 544-569). London: Palgrave Macmillan UK.

Kohn, M., \& Reddy, K. (2017). Colonialism. In E. N. Zalta (Ed.), The Stanford Encyclopedia of Philosophy: Stanford University, Retrieved from: https://plato.stanford.edu/archives/fall2017/entries/colonialism/.

McCormick, T. L. (1967). China Market: America's Quest for Informal Empire, 1893-1901. Chicago: Quadrangle Books.

McKelvey, C. (2016). United States Imperialism in the Western Hemisphere. In I. Ness \& Z. Cope (Eds.), The Palgrave Encyclopedia of Imperialism and Anti-Imperialism (pp. 755-765). London: Palgrave Macmillan UK.

Moscoso, F., \& González Vales, L. E. (2012). Economía. 1492-1816. In L. E. González Vales \& M. D. Luque (Eds.), Historia de Puerto Rico (Vol. IV, pp. 91-134). Madrid: Consejo Superior de Investigaciones Científicas; Doce Calles.

MUS. (2016). Borrador del Tratado de Libre Asociación entre el Estado Soberano de Puerto Rico y los Estados Unidos de América. Retrieved from https://drive.google.com/drive/folders/0BwpuLUSUMorlTzNkX2ppM0tHd28?usp=sharing.

Neveling, P. (2015). Export processing zones, special economic zones and the long march of capitalist development policies during the Cold War. In L. James \& E. Leake (Eds.), Negotiating independence: New directions in the histories of the Cold War \& decolonization (pp. 63-84). London: Bloomsbury.

Neveling, P. (2016). Free trade zones, export processing zones, special economic zones and global Imperial formations 200 BCE to 2015 CE. In I. Ness \& Z. Cope (Eds.), The Palgrave encyclopedia of imperialism and anti-imperialism (pp. 1007-1016). London: Palgrave Macmillan UK.

Neveling, P. (2017). The Global Spread of Export Processing Zones and the 1970s as a decade of consolidation. In K. Andersen \& S. Müller (Eds.) Changes in Social Regulation - State, Economy, and Social Protagonists since the 1970s (pp. 23-40). Oxford: Berghahn Books.Newkirk II, V. R. (2016). Puerto Rico Belongs to Congres. The Atlantic, 10 June, Retrieved from: https://www.theatlantic.com/politics/archive/2016/06/puerto-rico-news-ruling-promesa/486392/.

Nkrumah, K. (2002). Neo-Colonialism: The Last Stage of Imperialism. Bedford: Panaf Books.

Olson, G. (2016). United States Imperialism, 19th Century. In I. Ness \& Z. Cope (Eds.), The Palgrave Encyclopedia of Imperialism and Anti-Imperialism (pp. 766-773). London: Palgrave Macmillan UK.

Osterhammel, J. (1997). Colonialism. A Theoretical Overview. Princeton, NJ: Marcus Wiener. 
Pérez Soler, A. (2016). Asamblea Constitucional de Estatus, mecanismo procesal para la descolonización de Puerto Rico. 80 grados, 29 January, Retrieved from: https://www.80grados.net/asamblea-constitucional-deestatus-mecanismo-procesal-para-la-descolonizacion-de-puerto-rico/.

PIP. (2012). Lo que debes saber sobre la independencia. Retrieved from http://independencia.net/images/pdf/lo-que-debes-saber-sobre-la-independencia.pdf.

Powell, C. (2003). Memorandum to Belize Embassy concerning "possible Puerto Rican Requests for Recognition”, May 16, Retrieved from: http://puertoricorepo.wpengine.com/wpcontent/uploads/2012/03/TAB_9_Powell_May162003.pdf.

Puerto Rico Report. (2011). Puerto Rico is a Territory of the United States. 3 July, Retrieved from: https://www.puertoricoreport.com/puerto-rico-is-a-territory-of-the-united-states/ - .XC0qHmT0n-n.

Quintero Rivera, A. (1980). Background to the Emergence of Imperialist Capitalism in Puerto Rico. In A. Lopez (Ed.), The Puerto Ricans: Their History, Culture and Society. Cambridge, MA: Scfaenkman Publishing Company.

Raben, R. (2001). Letter to Sen. Frank H. Murkowski. Washington DC: US Department of Justice, January 18, Retrieved from: https://www.puertoricoreport.com/wpcontent/uploads/2012/03/TAB_5_Raben_Jan182001-2.pdf.

Rasmussen Reports. (2017). Americans Support Statehood for Puerto Rico More than D.C., 02 March, Retrieved from: http://www.rasmussenreports.com/public_content/politics/general_politics/february_2017/americans_supp ort_statehood_for_puerto_rico_more_than_d_c.

Statham Jr., E. R. (2002). Colonial Constitutionalism. The Tyranny of United States' Offshore Territorial Policy and Relations. Lanham: Lexington Books.

Steward, J. (1956). The people of Puerto Rico. Urbana: University of Illinois Press.

Telesur. (2015). Ley de cabotaje estadounidense fractura economía de Puerto Rico, 22 April, Retrieved from: https://www.telesurtv.net/news/Ley-de-cabotaje-estadounidense-fractura-economia-de-Puerto-Rico20150422-0056.html.

Torruella, J. R. (2018). Why Puerto Rico Does Not Need Further Experimentation with Its Future: A Reply to the Notion of "Territorial Federalism". Harvard Law Review, 131(3), 65-104.

Trias Monge, J. (1997). Puerto Rico: The Trials of the Oldest Colony in the World. New Haven: Yale University Press. 
US Congress. (2016). PROMESA. S.2328 - 114th Congress (2015-2016), Retrieved from: https://www.congress.gov/bill/114th-congress/senate-bill/2328.

US Court of Appeals. (2001). Xavier Romeu v. William S Cohen Secretary of Defense of the United States. 265 F. 3d 118, Retrieved from: https://openjurist.org/265/f3d/118/xavier-romeu-v-william-s-cohensecretary-of-defense-of-the-united-states.

US Department of Justice. (2015). Brief for the United States as Amicus Curiae supportung respondents. Washington DC, Retrieved from: https://www.puertoricoreport.com/wp-content/uploads/2016/01/15-108bsac-Puerto-Rico-v.-Sanchez-Valle-2.pdf.

US Supreme Court. (1901). Downes v. Bidwell, 182 U.S. 244. Retrieved from https://supreme.justia.com/cases/federal/us/182/244/.

US Supreme Court. (1922). Balzac v. Porto Rico, 258 U.S. 298, Retrieved from: https://supreme.justia.com/cases/federal/us/258/298/.

US Supreme Court. (1979). Torres v. Puerto Rico, 442 U.S. 465, 470-473 Retrieved from: http://caselaw.lp.findlaw.com/scripts/getcase.pl?navby=case \&court=us\&vol=442\&invol=465.

US Supreme Court. (1980). Harris v. Rosario,446 U.S. 651, 651-52. Retrieved from: http://caselaw.lp.findlaw.com/scripts/getcase.pl?navby=case \&court=us\&vol=446\&invol=651.

US Supreme Court. (2016). Commonwealth of Puerto Rico v. Sanchez Valle et al. 136 S.Ct 1863, Retrieved from: https://supreme.justia.com/cases/federal/us/579/15-108/.

Valentín-Mari, J. (2014). Impacto Económico de las Leyes de Cabotaje sobre Puerto Rico, 5 September, Retrieved from http://gis.jp.pr.gov/Externo_Econ/Talleres/Impacto Economico Cabotaje JPPR 5 Sept 2014.pdf.

Vazquez-Lazo, N. (2017). Las consecuencias de la ciudadanía americana en 1917. La Voz del Centro, 19 March, Retrieved from: http://www.vozdelcentro.org/2017/03/19/735-las-consecuencias-de-la-ciudadaniaamericana-en-1917/.

Wolf, R. (2016). Puerto Rico not sovereign, Supreme Court says. USA Today, 9 June, Retrieved from: https://www.usatoday.com/story/news/politics/2016/06/09/supreme-court-puerto-rico-independentsovereign/85155382/.

Young, D. (2017). House Floor Statement before House Session. Congressional Record, June 15, p. H4934, Retrieved from: https://www.puertoricoreport.com/wp-content/uploads/2011/07/Rep.-Don-Young-R-AKHouse-Floor-Statement-before-House-Session-June-15-2017-Congressional-Record-page-H4934..pdf. 
